\title{
Oculocutaneous albinism with iridofundal coloboma
}

\author{
Gunjan Saluja, ${ }^{1}$ Shorya Vardhan Azad, ${ }^{1}$ Amar Pujari, ${ }^{2}$ Shreyas Temkar $^{3}$
}

${ }^{1}$ Dr Rajendra Prasad Centre for Ophthalmic Sciences, All India Institute of Medical Sciences, New Delhi, India

${ }^{2}$ Department of Ophthalmology, Dr Rajendra Prasad Centre for Ophthalmic Sciences, All India Institute of Medical Sciences, New Delhi, India

${ }^{3}$ Department of Ophthalmology, Dr Rajendra Prasad Centre for Ophthalmic Sciences, All India Institute of Medical Sciences., New Delhi, India

\section{Correspondence to} Dr Shorya Vardhan Azad, shoryaazad@hotmail.com

Accepted 6 January 2018

\section{DESCRIPTION}

A 20-year-old woman presented to the retina clinic with complaints of diminution of vision, photophobia and involuntary movement of both eyes since birth. The patient had light-coloured skin complexion along with golden hair. Best corrected visual acuity was $1 / 60$ and $4 / 60$ in the right and left eyes, respectively. Ocular examination revealed manifest nystagmus, but there was no evidence of squint or head posture. The anterior segment had clear cornea and lens, with colobomatous light-coloured iris. Fundus examination in the right eye showed diffusely hypopigmented fundus with a large, well-defined excavated area along the inferior and nasal quadrant, extending well above the optic disc and the macula, suggestive of type I iridofundal coloboma (figure 1). Similarly, in the left eye, there was diffuse hypopigmentation except at the macula. Retinal and choroidal vessels were well appreciated along with their drainage into the vortex veins (figure 2). Based on these classical ocular and cutaneous findings, a diagnosis of oculocutaneous albinism with right-sided fundal coloboma was made. The patient was counselled about the nature of the disease and advised for refractive correction, dark-tinted glasses for photophobia and kept under follow-up.

Oculocutaneous albinism is a rare genetic disorder characterised by the complete or partial absence of melanin pigment from the skin, eyes and hairs. The worldwide prevalence has been estimated to be around 1 in $17000 .^{1}$ There are various types and classifications of albinism, but broadly they can be divided into oculocutaneous and ocular albinism. The oculocutaneous type is further subclassified into tyrosine-positive and tyrosine-negative variants

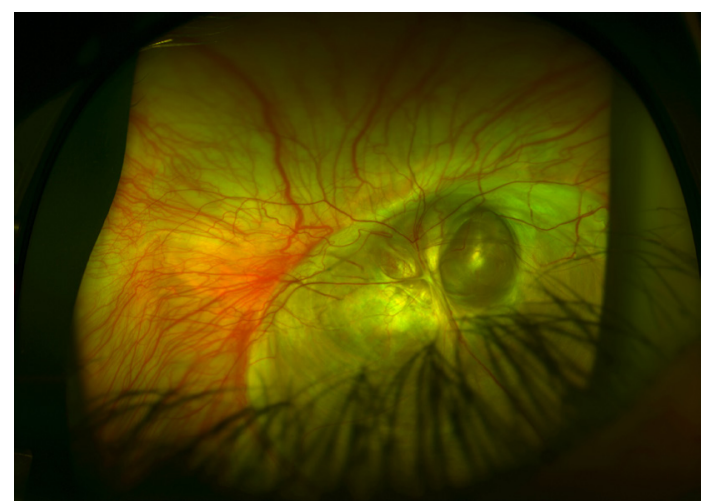

To cite: Saluja G, Azad SV, Pujari A, et al. BMJ Case Rep Published Online First: [please include Day Month Year]. doi:10.1136/bcr-2017223799
Figure 1 Right eye fundus showing diffuse hypopigmentation along with excavated lesion involving the inferior and nasal retina. The optic disc and macula iridofundal coloboma. were within the colobomatous area suggestive of type I

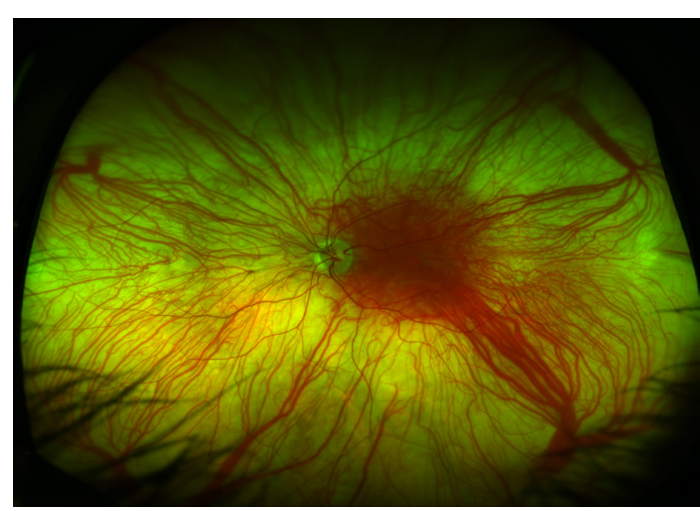

Figure 2 Left eye fundus showing similar kind of diffuse hypopigmentation sparing the macula with prominent retinochoroidal drainage into the vortex vein.

depending on the activity of tyrosinase enzyme, which is crucial for the synthesis of melanin. ${ }^{23}$

Coloboma of choroid occurs due to defective closure of the embryonic fissure of the developing optic vesicle. It can be an isolated disorder or associated with ocular or systemic abnormalities. Association with iridofundal coloboma has not been previously reported. Although the exact association between these two entities cannot be ascertained, their occurrence can either be coincidental or may be due to a defective genetic pathway. Genetic testing for specific genes may reveal any such association.

\section{Learning points}

Oculocutaneous albinism is rarely associated with iridofundal coloboma.

- Patients with oculocutaneous albinism might possess significant posterior segment pathology. Thus a detailed ocular evaluation is necessary.

Contributors GS, SVA, AP and ST have evaluated the case in detail. GS, SVA, AP and ST wrote the report together after critically analysing the educational value of the case.

Funding This research received no specific grant from any funding agency in the public, commercial or not-for-profit sectors.

Competing interests None declared.

Patient consent Obtained.

Provenance and peer review Not commissioned; externally peer reviewed.

(C) BMJ Publishing Group Ltd (unless otherwise stated in the text of the article) 2018. All rights reserved. No commercial use is permitted unless otherwise expressly granted.

\section{REFERENCES}

1 Grønskov K, Ek J, Brondum-Nielsen K, et al. Oculocutaneous albinism. Orphanet J Rare Dis 2007;2:43. 


\section{Images in...}

2 Wildsoet CF, Oswald PJ, Clark S. Albinism: its implications for refractive development. Invest Ophthalmol Vis Sci 2000;41:1-7.

3 Onwochei BC, Simon JW, Bateman JB, et al. Ocular colobomata. Surv Ophthalmol 2000;45:175-94.

Copyright 2017 BMJ Publishing Group. All rights reserved. For permission to reuse any of this content visit

http://group.bmj.com/group/rights-licensing/permissions.

BMJ Case Report Fellows may re-use this article for personal use and teaching without any further permission.

Become a Fellow of BMJ Case Reports today and you can:

- Submit as many cases as you like

- Enjoy fast sympathetic peer review and rapid publication of accepted articles

Access all the published articles

- Re-use any of the published material for personal use and teaching without further permission

For information on Institutional Fellowships contact consortiasales@bmjgroup.com

Visit casereports.bmj.com for more articles like this and to become a Fellow 